\title{
First observation of alternative food usage (extrafloral nectar) by the assassin bug Atopozelus opsimus (Hemiptera, Reduviidae)
}

\author{
Rhainer Guillermo-Ferreira ${ }^{1}$, Ricardo Cardoso-Leite ${ }^{1} \&$ Rafael Gandolfo $^{1}$
} ${ }^{1}$ Departamento de Biologia, Faculdade de Filosofia, Ciências e Letras de Ribeirão Preto, Universidade de São Paulo, Av. Bandeirantes, 3900,
14040-901, Ribeirão Preto-SP, Brazil. rhainerguillermo@yahoo.com.br

\begin{abstract}
First observation of alternative food usage (extrafloral nectar) by the assassin bug Atopozelus opsimus (Hemiptera, Reduviidae). Assassin bugs (Reduviidae) are voracious insects that prey on other arthropods. Recent evidences have pointed out that these predators also feed on plant derived substances in rare opportunities. The present study describes the feeding behavior of the reduviid Atopozelus opsimus on extrafloral nectaries of Inga vera (Fabaceae) in a Neotropical savanna area. It was investigated if the insects feed more frequently of extrafloral nectar or prey, and if individuals of different stages of development vary according to feeding behavior. Notably, the results suggest that the diet of all instars and adults consist mainly of extrafloral nectar $(\mathrm{N}=1013)$, in detriment of captured prey ingestion $(\mathrm{N}=18)$. Also, there was no variation on feeding behavior and life stage.
\end{abstract}

KEYWORDS. Foraging; Heteroptera; herbivory; Leguminosae; predator.

RESUMO. Primeira observação do uso de alimento alternativo (néctar extrafloral) pelo percevejo assassino Atopozelus opsimus (Hemiptera, Reduviidae). Percevejos assassinos (Reduviidae) são insetos vorazes que predam outros artrópodes. Evidências recentes têm mostrado o interessante fato de que estes predadores também se alimentam de substâncias derivadas de plantas. Embora intrigante, este comportamento é raro e nenhum estudo mostrou quão comum este comportamento é quando comparado com o comportamento de caça. Portanto, o presente estudo descreve o comportamento alimentar do reduvídeo Atopozelus opsimus em nectários extraflorais de Inga vera (Fabaceae). Foi investigado se os insetos se alimentam mais frequentemente de nectar extrafloral ou de presas, e se indivíduos de diferentes estágios de desenvolvimento variam de acordo com o comportamento alimentar. Notavelmente, os resultados sugerem que a dieta de todos os ínstares ninfais e dos adultos consiste principalmente de néctar extrafloral $(\mathrm{N}=1013)$, em detrimento da ingestão de presas capturadas $(\mathrm{N}=18)$. Também, não houve variação no comportamento de alimentação de acordo com a idade.

PALAVRAS-CHAVE. Forrageamento; Heteroptera; herbivoria; Leguminosae; predador.

Extrafloral nectaries (EFNs) are secretory glands not directly involved with pollination (Fiala \& Machwistz 1991), which may occur in all vegetative and reproductive plant parts in more than 90 angiosperm families (Koptur 1992). EFNs bearing plants can be found in both tropical and temperate zones, although they are more common in tropical areas (Morellato \& Oliveira 1994).

A large group of animals are attracted to EFNs (Koptur 1992), such as spiders (Ruhren \& Handel 1999; Nahas et al. 2012) and ants (Oliveira \& Brandão 1991; Nascimento \& Del-Claro 2010) which provide protection to the plant against herbivores. In return, the animals get the nectar which is an important part of nutrition and can enhance growth and reproduction (Byk \& Del-Claro 2011).

Ralston (1977) and Tallamy et al. (2004) briefly mentioned observations of a reduviid (Atopozelus pallidens) drinking nectar from EFNs. Reduviids are commonly known as "assassin bugs" due to their remarkable predatory behavior. However, although rare, some species seem to complement their diet by drinking floral (Narbona \& Dirzo 2010) and extrafloral nectar (Ralston 1977; Tallamy et al. 2004) or sucking the sap from the plant by perforating plant tissue (Haviland 1931; Stoner et al. 1975).

For some species, it is suggested that the ingestion of plant substances may be necessary to synthesize a sticky material through female metabolism (Choe \& Rust 2007). However, not only females feed on plant substances but also males and nymphs. In this case, such substances may play a role on insect nutrition, since nymphs can develop to adulthood by feeding only on plant derived materials (Stoner et al. 1975).

Considering that Tallamy et al. (2004) reported that nymphs and adults of the reduviid $A$. pallidens feed on extrafloral nectaries in Costa Rica tropical forests, here we studied the case of A. opsimus Elkins (1954), a common species in Southeastern Brazil (Dias et al. 2012).

This species is considered to be a predator of psyllids (Dias et al. 2012) and, so far, there was no report of phytophagy for this species. Thus, we investigated the diet and feeding behavior of nymphs and adults on Inga vera (Fabaceae), a EFN bearing plant, testing the hypothesis that the EFNsucking behavior in A. opsimus represent a complementary diet to the carnivorous behavior.

\section{MATERIAL AND METHODS}

The study was performed on a Inga vera tree in the Sao Paulo State University located in a Neotropical Savanna area in Assis, Brazil (22 64 'S, $50^{\circ} 43^{\prime} \mathrm{W}$; altitude $522 \mathrm{~m}$ ). We made 30 hours of behavioral observations consisting of six sessions of five minutes made on each hour, with intervals of 
five minutes between them (scanning sample, see Altmann 1974). We took care of observing one branch at a time to avoid sampling the same individual on each session. Three observers alternated between sessions hourly.

We did not mark nymphs to avoid disturbance and loss of marking during ecdysis. Nymphs could be found under the leaves most of the time, climbing them up to drink on EFNs or try to catch prey. Both behaviors last less than the observation sessions. Thus, we consider that the five minutes intervals between sessions were sufficient time to allow them to hide back until they fed again.

Observations were made during daylight $(9 \mathrm{~h}-19 \mathrm{~h})$ when the individuals were active on the plant. Between $18 \mathrm{~h}$ and $19 \mathrm{~h}$ the insects reduced their activity. We made additional observations during the early morning (before $9 \mathrm{~h}$ ) and the night (after 19h) and noted that the individuals presented no activity and remained hidden under the leaves.

We divided individuals in four different age categories: (i) small (first and second instar nymphs, identified by their yellowish color, absence of yellow stripes on abdomen and red stripes on legs); (ii) medium size (third and fourth instar nymphs, identified by their green color, the presence of yellow stripes on abdomen and red stripes on legs); large (last instar nymphs, identified by the presence of wing pads); and (iv) adults (identified by the developed wings) (based on Coscaron et al. 2002).

In each session, we quantified for each age category the number of: (a) nymphs feeding on EFNs; (b) nymphs feeding on prey. Thus, to investigate if carnivory is more common than phytophagy in this species, we compared the frequencies (number of observations per hour) of hunting behavior and nectar feeding, regardless of age, using the Mann-Whitney "U" test, since data was not normally distributed (Shapiro-Wilk test, $\mathrm{p}<0.01)$. To investigate if individuals of different age categories present variations in relation to food resources usage, we made G-tests comparing the number of observations per hour for each age category. All statistical analyzes were made using the software Statistica $9^{\circledR}$.

\section{RESULTS}

Bugs fed more in EFNs $(\mathrm{N}=1013$, Fig. 1) than on prey items $(\mathrm{N}=114)$. The results show that nectar feeding $(103.3$ \pm 66.38 per hour) is much more frequent than hunting behavior (15 \pm 9.58 per hour) (Mann-Whitney, $\mathrm{U}=8.5$; $\mathrm{df}=$ $18 ; \mathrm{p}=0.0017)$.

When not active on the plant, the nymphs and adults remained immobile under leaves. The nymphs of different instars shared the same shelter, but no cannibalism was observed. Adults and large nymphs were observed guarding eggs and smaller nymphs.

The G-tests shows that there is no variation between age categories in nectar feeding $(\mathrm{G}$-test $=10.4 ; \mathrm{df}=27 ; \mathrm{p}=0.99)$ and hunting frequencies ( $\mathrm{G}$-test $=26.69 ; \mathrm{df}=27 ; \mathrm{p}=0.48$ ). We also observed that individuals were successful in catching prey in only 18 cases, although there were many insects visiting extrafloral nectaries. The bugs avoided contatct with ants and spiders that also visited extrafloral nectaries. The captured preys are Tetragonisca angustula (Hymenoptera, $\mathrm{N}=4$ ), Curculionidae (Coleoptera, 1), Thephritidae/Drosophilidae (Diptera, $\mathrm{N}=8$ ), Cicadellidae (Homoptera, $\mathrm{N}=4$ ) and Coreidae (Heteroptera, $\mathrm{N}=1$ ).

\section{DISCUSSION}

Our results suggest that non-prey items, specifically extrafloral nectar, may play an important role on their diet. Recent evidences have shown that such food resource may be crucial for insect development (Byk \& Del-Claro 2011) and is part of the diet of many predatory arthropods like ants (Nascimento \& Del-Claro 2010) and spiders (Nahas et al. 2012). Since nymphs of $A$. opsimus may feed more frequently on nectar than on prey, plant derived substances may even be enough for nymph development like Stoner et al. (1975) suggested.

From these results, we make three suppositions on why these bugs preferred nectar. First, nectar feeding may be even more important than a diet composed of mainly protein sources such as prey. Extrafloral nectar is a source of water, sugars and amino acids (Koptur 1992; González-Teuber \& Heil 2009) which can be nutritive enough to developing nymphs. Indeed, recent evidences show the nutritive potential of EFN, which can improve ant colonies growth and development (Byk \& Del-Claro 2011).

Second, predatory bugs may choose nectar instead of prey because there is injury risk during prey capturing and low success while hunting. As an example of injury risk avoidance, we observed some $A$. opsimus avoiding contact with ants and spiders. Animals are predicted to optimize energetic expenditure and evaluate injury risk while hunting for prey (e.g. Berger-Tal et al. 2009).

Third, the tropical and warm climate in the Neotropical Savannas can be an important factor in nymph development, since it can cause dehydration. EFNs than can be a valuable water source. Additionally, when hunting, these insects raise their forelegs, which have glands that secret a sticky substance used to catch prey (Zhang \& Weirauch 2011) which can demand the ingestion of water for its production.

Our results also suggest that different stages of development explore food resources similarly. Since adult females need to consume plant derived substances to produce eggs (Choe \& Rust 2007), some would expect that only adult females would consume nectar. If all stages feed on EFN, older stages should invest more on prey hunting, rether than drinking nectar, because their larges bodies could minimize the risk of injury. However, the results show there was no clear difference in the way individuals of different ages consumed nectar or prey.

In conclusion, the phytophagous behavior is present in this A. opsimus population just like Ralston (1977) and Tallamy et al. (2004) recorded for A. pallens. Reduviids belong to the second largest heteropteran family with more than 6250 species distributed in 913 genera (Maldonado 1990), but such behavior seems to be present only in the genus Atopozelus. 

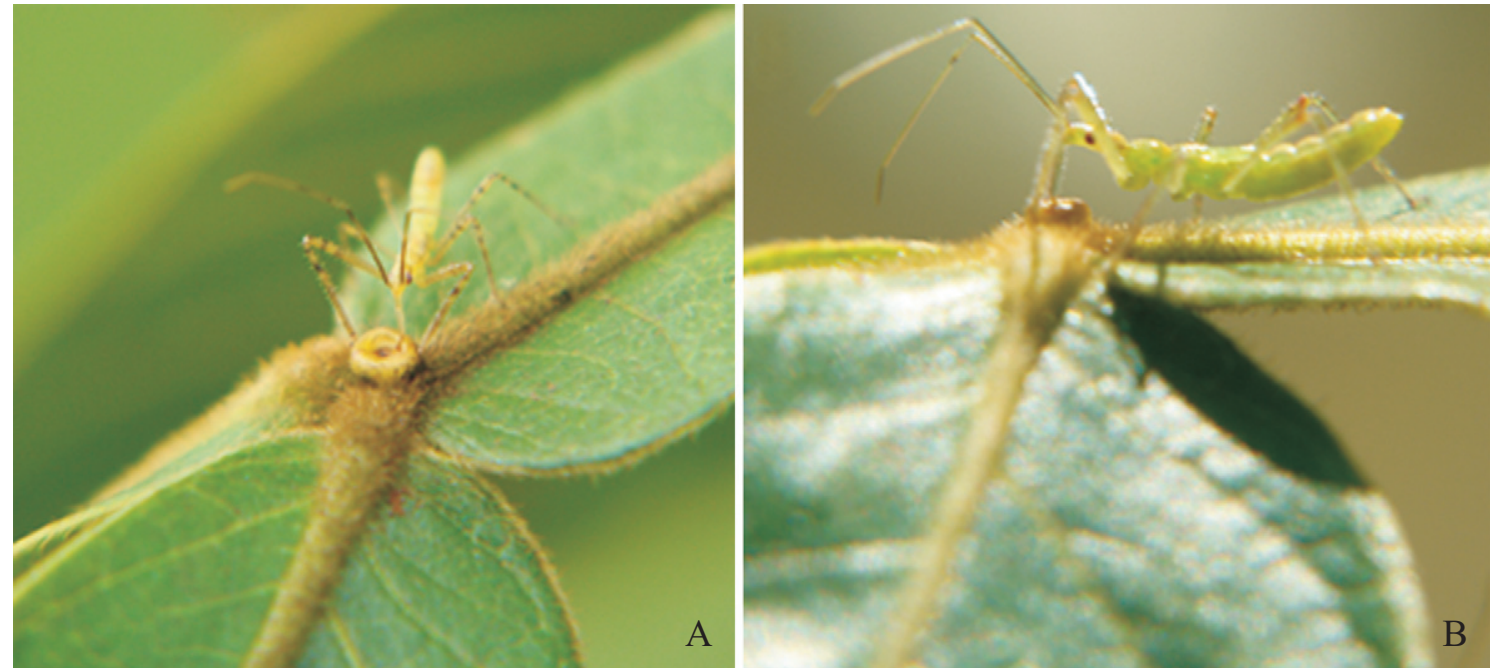

Fig. 1. Small (A) and large (B) nymphs of the assassin bug Atopozelus opsimus (Reduviidae) feeding on extrafloral nectaries of Inga vera.

Considering that other study reported a carnivorous predominant behavior in this species (Dias et al. 2012), future studies should address which variables drive the phytophagous behavior in assassin bugs.

\section{ACKNOWLEDGEMENTS}

We thank Guanyang Zhang for helping with insect identification. We also thank Aurelio Fajar Tonetto for valuable comments on the manuscript. We thank CAPES for constant financial support.

\section{REFERENCES}

Altmann, J. 1974. Observational study of behaviour: sampling methods. Behaviour 49: 227-267.

Berger-Tal, O.; S. Mukherjee; B. P. Kotler \& J. S. Brown. 2009. Look before you leap: is risk of injury a foraging cost? Behavioral Ecology and Sociobiology 63: 1821-1827.

Byk, J. \& K. Del-Claro. 2011. Ant-plant interaction in the Neotropical savanna: direct beneficial effects of extrafloral nectar on ant colony fitness. Population Ecology 53: 327-332.

Choe, D. -H. \& M. K. Rust. 2007. Use of plant resin by a bee assassin bug Apiomerus flaviventris (Hemiptera: Reduviidae). Annals of the Entomological Society of America 100: 320-326.

Coscarón, M. del C.; P. M. Dellapé \& K. Del-Claro. 2002. Immature Stages of Zelus leucogrammus (Heteroptera: Reduviidae). Journal of the Kansas Entomological Society 75: 31-37.

Dias, T. K. R.; C. F. Wilcken; E. P. Soliman; H. Gil-Santana \& B. Zaché. 2012. Occurrence of Atopozelus opsimus preying on nymphs and adults of Glycaspis brimblecombei. Phytoparasitica 40: 137-141.

Fiala, B. \& U. Machwistz. 1991. Extrafloral nectaries in the genus Macaranga (Euphorbiaceae) in Malaysia: comparative studies of their possible significance as predispositions for myrmecophytism. Biological Journal of the Linnean Society 44: 287-305.

González-Teuber M. \& M. Heil. 2009. The role of extrafloral nectar amino acids for the preferences of facultative and obligate ant mutualists.
Journal of Chemical Ecology 35: 459-468

Haviland, M. D. 1931. The Reduviidae of Kartabo, Bartica. District, British Guiana. Zoologica 7: 129-154.

Koptur, S. 1992. Extrafloral nectaries-mediated interactions between insects and plants, p. 81-129. In: E. Bernays (ed.) Insect-Plant interactions, vol. 4, Boca Raton, CRC Press, 487p

Maldonado, C. J. 1990. Systematic Catalogue of the Reduviidae of the World (Insecta: Heteroptera). Caribbean Journal Science, Special publication number $1,694 \mathrm{p}$.

Morellato, L. P. C. \& P. S. Oliveira. 1994. Extrafloral nectaries in the tropical tree Guarea macrophylla (Meliaceae). Canadian Journal of Botany 72: $157-160$.

Nahas, L.; M. O. Gonzaga \& K. Del-Claro. 2012. Emergent Impacts of Ant and Spider Interactions: Herbivory Reduction in a Tropical Savanna Tree. Biotropica 44: 498-505.

Narbona, E. \& R. Dirzo. 2010. A reassessment of the function of floral nectar in Croton suberosus (Euphorbiaceae): a reward for plant defenders and pollinators. American Journal of Botany 97: 672-679.

Nascimento, E. A. do \& K. Del-Claro. 2010. Ant visitation to extrafloral nectaries decreases herbivory and increases fruit set in Chamaecrista debilis (Fabaceae) in a Neotropical savanna. Flora 205: 754-756.

Oliveira, P. S. \& C. R. F. Brandão. 1991. The ant community associated with extrafloral nectaries in Brazilian cerrados, p. 198-212. In: D. F. Cutler \& C. R. Huxley (eds.). Ant-Plant Interactions. Oxford, Oxford University Press, 624 p.

Ralston, J. S. 1977. Egg guarding by male assassin bugs of the genus Zelus (Hemiptera: Reduviidae). Psyche 87: 103-107.

Ruhren, S. \& S. N. Handel. 1999. Jumping spiders (Salticidae) enhance the seed production of a plant with extrafloral nectaries. Oecologia 119 227-230.

Stoner, A.; A. M. Metcalfe \& R. E. Weeks. 1975. Plant feeding by Reduviidae, a predaceous family (Hemiptera). Journal of the Kansas Entomological Society 48: $185-188$.

Tallamy, D. W.; E. Walsh \& D. C. Peck. 2004. Revisiting Paternal Care in the Assassin Bug, Atopozelus pallens (Heteroptera: Reduviidae). Journal of Insect Behavior 17: 431-436.

Zhang, G. \& C. Weirauch. 2011. Sticky predators: a comparative study of sticky glands in harpactorine assassin bugs (Insecta: Hemiptera: Reduviidae). Acta Zoologica (Stockholm): 1-10. doi: 10.1111/j.14636395.2011.00522.x 